the growing demands from nations which are becoming wheat-eaters all point to a reduced supply for Great Britain. That our production can be increased becomes evident from a comparison of the figures for different years, e.g. in $186816,733,000$ quarters of wheat were produced compared with $6,677,000$ quarters in 1920.

During the war patriotism was certainly one of the controlling factors in the production of home-grown wheat, but now that conditions are more or less normal price becomes the dominant factor. The Agriculture Act has considerably changed the position of the wheat-grower in this country, and with a free and uncontrolled market, as well as a guarantee against loss in the event of the world's price falling below the cost of production, the growing of wheat becomes an attractive scheme. The guarantee is based on the acreage sown, and not on the quantity of grain per acre, and the four-quartersper-acre basis for the guarantee should be a stimulus to the light-land farmer to grow wheat, while on heavy land and "wheat-land" there is the stimulus of a higher return on account of the greater yields. Probably the best way to increase production is to raise the average yield per acre throughout the country.

The Harper-Adams Agricultural College has been carrying out tests for some years, and the results show what large differences exist between the yielding powers of different varieties. In a three-year average the "Standard" variety of wheat showed a yield of 33 bushels per acre, while "Svalof Iron", headed the list with 56 bushels per acre, so that it is obvious that by using some of the new higher yielding varieties the yield per acre could be considerably increased. At one time Great Britain boasted that her average wheat yield per acre was higher than that of any other country in the world, but the figures for IgIa show that we are now below other countries, the yield for Denmark being 47.5 bushels per acre against 29. I bushels per acre in Great Britain.

Judicious manuring is one of the surest aids to increased yield, and even at present prices an increase of three bushels per acre amply repays the application of I cwt. of sulphate of ammonia. Other points to be considered are the time and the rate of sowing. All available experiments seem to favour the autumnsown wheat, while it seems very probable that a big saving could be effected by reducing the amount of seed sown per acre.

\section{Hydrography of the Nile Basin.}

$\Gamma$ $\mathrm{HE}$ hydrographical data relating to the Nile and its upper reaches were published last year by the Public Worlss Ministry of Egypt in a report entitled "Nile Control," which was reviewed in these columns on December 30 last. The information was collected for the use of the Technical Commission which was appointed last year to report upon the various projects prepared by the Ministry for controlling and distributing the Nile waters in Egypt and the Sudan. The report of the Commission has now been published ("Report of the Nile Projects Commission," Cairo, 1920). The Commission consisted of two hydraulic engineers of wide experience, Mr. F. S. J. Gebbie, nominated by the Government of India, and Mr. H. F. Cory, nominated by the Government of the United States; also of Dr. G. C. Simpson, nominated by the University of Cambridge as a physicist whose scientific knowledge and experience were desired in connection with problems in water measurement. Criticism of the projects had been rife for many No. 268 I, VOL. IO7] months, and had culminated in a series of charges being brought against the Ministry of Public Works by Sir W. Willcocks and Col. Kennedy, in which falsification of data and suppression of records were alleged. More than half of the report is taken up by a consideration of these charges by the Commission, which has reported unanimously that there had been no falsification or any fraudulent manipulation of data.

Passing to the consideration of the technical merits of the projects for the dams at Gebel Aulia on the White Nile and at Sennar on the Blue Nile, for the barrage at Nag' Hamadi in Upper Egypt, for a dam on the upper reaches of the Blue Nile and for another on Lake Albert, the Commission reports wholly in favour of each of them. It does not consider that proposals for the construction of reservoirs in the marsh region of the White Nile are worthy of investigation. The further terms of reference, the allocation of the increased supply of available water and the apportionment of cost, produced a minority report from $\mathrm{Mr}$. Cory. On the measurement of river discharges the Commission expresses the opinion that there is no other river in the world for which the discharge is so accurately determined as that of the Nile, and its report bears out what has been fully set out in "Nile Control," that the present-day needs of Egypt and the Sudan demand the highest precision in the control and distribution of the Nile water. The addition of a Physical Department to the Ministry of Public Works indicates that this has been recognised, and it is to be hoped that when a fuller measure of responsibility is placed upon Egyptian administrators they too will realise the necessity for maintaining the highest efficiency in all that concerns the scientific study of the hydrography of the Nile basin.

\section{University and Educational Intelligence.}

Birmingham.-Mr. John G. Garrett has been ap. pointed lecturer and demonstrator in mine surveying, and Mr. John P. Rees lecturer in metal mining.

The following new members of the staff of Queen's Hospital have been appointed University clinical teachers:-Dr. Geoffrey Eden, assistant lecturer on clinical medicine and junior medical tutor, and $\mathrm{Mr}$. W. Gemmill, assistant lecturer on clinical surgery.

EDINBURGH.-The committee organised in I9I I by the late Prof. MacGregor to promote a memorial to Prof. Tait in the form of a second chair of natural philosophy is now in a position to report to the sub. scribers and others interested that the Tait chair will shortly be established. The funds collected before the war have now been substantially augmented by sums from other sources, and the committee, after conferring with the University Court, has been informed by it that it will be possible to arrange for the founda. tion of the chair not later than the year 1925 , by which time certain funds set aside by the University Court towards the endowment of the chair will have matured. In announcing this gratifying decision the Tait Memorial Committee believes that there are still many of Prof. Tait's former pupils and friends desirous of being associated in the promotion of this lasting memorial to a great natural philosopher. Further and immediate contributions will make it possible to inaugurate the Tait chair of natural philosophy before 1925 . Further information may be obtained from the hon. secretary, Dr. C. G. Knott, University of Edinburgh. 